\title{
A rare case of Conradi-Hunermann-Happle syndrome
}

\section{Fatima Tuz Zahra', Mohammad Adil', Syed Suhail Amin'1, Mahtab Alam¹, Annu Priya', Shadma Shahin ${ }^{2}$}

${ }^{1}$ Department of Dermatology, Jawaharlal Nehru Medical College (JNMC), Aligarh Muslim University (AMU), Aligarh, India, ${ }^{2}$ Department of Pathology, Jawaharlal Nehru Medical College (JNMC), Aligarh Muslim University (AMU), Aligarh, India

Corresponding author: Dr. Mohammad Adil, E-mail: dr.mohd.adil@gmail.com

Sir,

Conradi-Hunermann-Happle Syndrome is a rare type of chondrodysplasia punctata that presents with ichthyosis, asymmetry of limbs, short stature, and less frequently cataracts, ichthyosiform erythroderma, epiphyseal stippling and craniofacial defects $[1,2]$. It is $\mathrm{X}$ linked dominant disorder with mutation in the gene emopamil binding protein (EBP) located on short arm of $\mathrm{X}$ chromosome. EBP gene encodes 8-7 sterol isomerase which is involved in the cholesterol biosynthesis [3]. In this report, a case of a 9-yearsold girl diagnosed with Conradi-Hunermann-Happle syndrome with a typical clinical picture is reported.

A 9 years old female presented to the Out Patient Department with 7 years history of generalized linear and swirling pattern of hyperpigmentation along with dry, thickened skin and coarse, lusterless hair. The patient was born at full term with normal delivery and unremarkable family history. Her mother gave a history of red scaly skin at birth that resolved by 1 year of age. The patient's father and mother had non-consanguineous marriage. Parents and the two siblings were healthy.

Dermatological examination revealed hyperkeratotic plaques with thick adherent scales and accentuation of skin markings over the extremities and buttock (Fig. 1). Bilaterally symmetrical brown linear streaks were present on upper and lower limbs. Atrophoderma was present on back and limbs. She displayed short stature, palmoplantar hyperkeratosis and dystrophy of nails. Thinning of bilateral eyebrows with flat nasal bridge was present (Fig. 2). Hair was coarse and lusterless with patchy alopecia. Bone and ocular findings were normal.

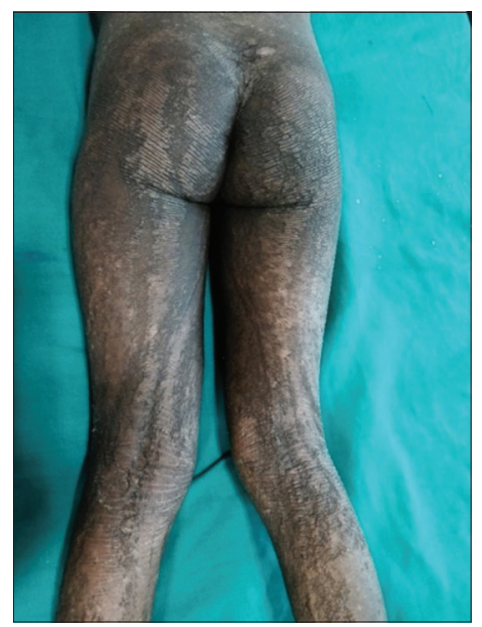

Figure 1: Hyperpigmented and hyperkeratotic plaques along the lines of Blaschko over the buttocks and lower extremities.

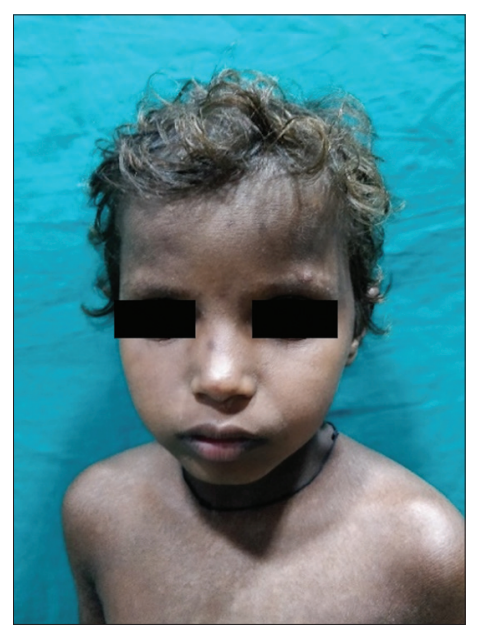

Figure 2: Sparse lusterless hair over the scalp and eyebrows with depressed nasal bridge.

The patient underwent biopsy which showed thick laminated orthokeratosis, and acanthosis of stratified

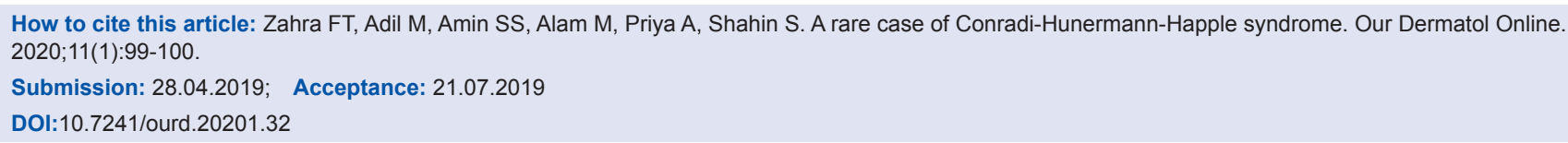




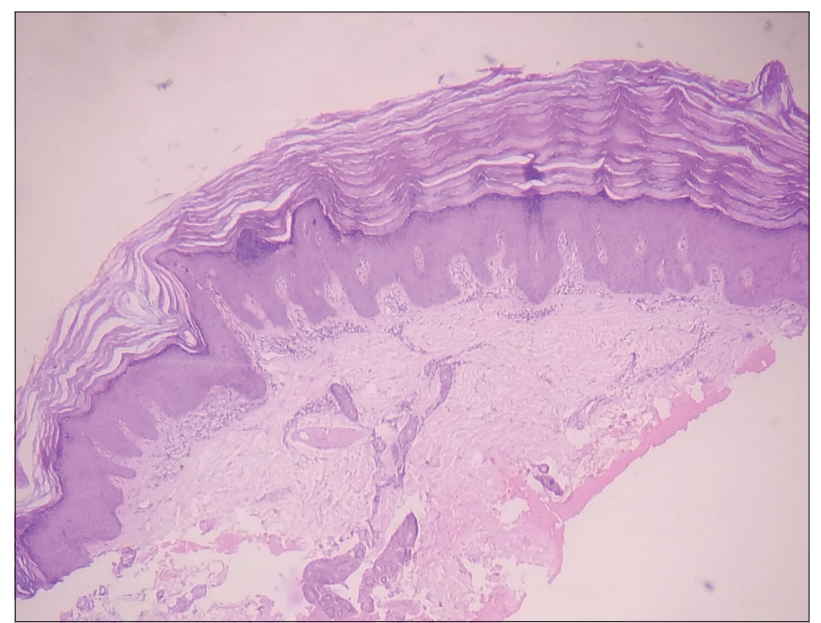

Figure 3: Histopathology from the hyperkeratotic plaque showed thick lamellated orthokeratosis, acanthosis and sparse lympho-histiocytic infiltrate in the dermis (H\&E, 10X).

squamous epithelium with lymphohistiocytic infiltrate and few pilosebaceous units in the dermis (Fig. 3). X-ray of the spine and limbs were normal.

Conradi-Hunermann-Happle Syndrome presents with hyperkeratotic lesions on erythematous base with linear or blotchy ichthyosis in the lines of Blaschko. It resolves to leave linear or whorled pattern of atrophoderma and pigmentary abnormalities. Patients also present with asymmetry of limbs, short stature, coarse hair and less frequently with cataracts, epiphyseal stippling and craniofacial defects $[1,4]$. It is a rare genetic disorder that occurs almost exclusively in females, though small number of affected males are reported [5]. It shows increased disease expression in successive generations [6]. Therefore, genetic counselling, diagnostic DNA and prenatal diagnosis should be offered.

Diagnosis is based on dermatological, ophthalmic, radiographic and biochemical investigations. Clinical diagnosis can be confirmed by a sterol analysis of plasma or tissue in which levels of 8-dehydrocholestrol and 8(9)-cholestenol are elevated [3].
Our patient presented with some features typical of chondrodysplasia punctata such as short stature, erythroderma at birth, atrophoderma, ichthyotic and hyperkeratotic skin. Diagnosis was made based on clinical and histopathological features. Biochemical and molecular analysis could not be done due to financial constraints of the patient. This case is reported because of the rare nature of the disease and the classical presentation.

\section{Consent}

The examination of the patient was conducted according to the Declaration of Helsinki principles.

\section{REFERENCES}

1. Cañueto J, Girós M, Ciria S, Pi-Castán G, Artigas M, García-Dorado J, et al. Clinical, molecular and biochemical characterization of nine Spanish families with Conradi-Hünermann-Happle syndrome: new insights into X-linked dominant chondrodysplasia punctata with a comprehensive review of the literature. Br J Dermatol. 2012; 166:830-8.

2. Da Silva Figueiredo S, de Araujo DS, Kozan JEM, dos Santos NCL, Tanganeli V. Rhizomelic chondrodysplasia punctata: a case report and brief literature review. Radiol Bras. 2007;40:69-72.

3. Braverman N, Lin P, Moebius FF, Obie C, Moser A, Glossmann H, et al. Mutations in the gene encoding 3 beta-hydroxysteroid-delta 8 , delta 7-isomerase cause X-linked dominant Conradi-Hunermann syndrome. Nat Genet. 1999;89:564-71.

4. Ozurt K, Subasioglu A, Ozturk P, Inci R, Ozkan F, Bueno E, et al. Emopamil binding protein mutation in conradi-hünermann-happle syndrome representing plaque-type psoriasis. Indian J Dermatol. 2015;60:216.

5. Imrani K, Ayouche O, Dafiri R. New case of Conradi Hunerman Syndrome in a newborn male. Int J Adv Re.s 2018;6:372-5.

6. Has C, Bruckner-Tuderman L, Muller D, Floeth M, Folkers E, Donnai D, et al. The Concradi-Hunermann Happle syndrome (CDPX2) and emopamil binding protein: novel mutations, and somatic mosaicism. Hum Mol Genet. 2000;9:1951-5.

Copyright by Fatima Tuz Zahra, et al. This is an open-access article distributed under the terms of the Creative Commons Attribution License, which permits unrestricted use, distribution, and reproduction in any medium, provided the original author and source are credited.

Source of Support: Nil, Conflict of Interest: None declared. 